\title{
Urban areas, human health and technosols for the green deal
}

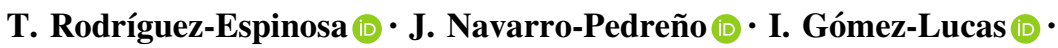 \\ M. M. Jordán-Vidal $(\mathbb{D} \cdot$ J. Bech-Borras $\mathbb{D} \cdot$ A. A. Zorpas $(\mathbb{D}$
}

Received: 3 January 2021 / Accepted: 20 April 2021 / Published online: 4 May 2021

(C) The Author(s), under exclusive licence to Springer Nature B.V. 2021

\begin{abstract}
Authors aim to carry out a bibliographic review as an initial approach to state of the art related to the quality of urban soils, as well as its possible link with human health. This concern arises from the need to highlight the consequences that soil could face, derived from the growth and aging of the population, as well as its predicted preference for urban settlement. Urban development may pose a challenge to the health of urban soils, due to degradative processes that it entails, such as land take, sealing, contamination or
\end{abstract}

T. Rodríguez-Espinosa ( $₫)$ · J. Navarro-Pedreño ·

I. Gómez-Lucas · M. M. Jordán-Vidal

Department of Agrochemistry and Environment, University Miguel Hernández of Elche, Avd. de la

Universidad s/n, 03202 Elche (Alicante), Spain

e-mail: maria.rodriguez34@goumh.umh.es

J. Navarro-Pedreño

e-mail: jonavar@umh.es

I. Gómez-Lucas

e-mail: ignacio.gomez@umh.es

M. M. Jordán-Vidal

e-mail: manuel.jordan@umh.es

J. Bech-Borras

Laboratory of Soil Sciences, Faculty of Biology, Plant

Biology, University of Barcelona, Barcelona, Spain

e-mail: jaumebechborras@gmail.com

A. A. Zorpas

Faculty of Pure and Applied Sciences, Laboratory of Chemical Engineering and Engineering Sustainability,

Open University of Cyprus, Environmental Conservation compaction. A healthy soil is the one which maintains the capacity to support ecosystem services, so it can provide numerous benefits to human health and wellbeing (carbon sequestration, protection against flooding, retention and immobilization of pollutants and a growth media for vegetation and food production). This article addresses threats facing urban soils, the strategies put forward by the European Union to deal with them, as well as the issues that require further attention. Greening cities could be a consensual

and Management, P.O. Box 12794, 2252 Latsia,

Nicosia, Cyprus

e-mail: antonis.zorpas@ouc.ac.cy 
solution, so authors analyze whether soils of cities are ready for that challenge and what resources need to maintain soil ecosystem functions. This review proposes to use made by waste Technosols for a sustainable green city. Although the use of Technosols as a type of soil is very recent, the interest of the scientific community in this field continues to grow.

Keywords Green infrastructure - Anthropogenic soils $\cdot$ Wastes $\cdot$ Ecosystem services $\cdot$ Soil sealing

\section{Introduction}

The consequences of climate change pose a growing threat to safety of cities and their inhabitants (Filho et al., 2019). This review has the intention to study the level of vulnerability of cities from the prism of soils and its relationship with human health.

Soils are a non-renewable resource (EC, 2020a), as it is not replenished with enough speed at which it is consumed. Further, the optimal functioning of soils is of great importance to provide ecosystem services (Brevik et al., 2018).

Soil current situation in Europe indicates that $60-70 \%$ of soils are unhealthy (EC, 2020a), implying more than $2,539,953 \mathrm{~km}^{2}$ affected, mainly due to management practices, and to a lesser extent, to air pollution and climate change (EC, 2020a). To contextualize the subject and content, authors provide specific data on the difficulties faced by soils (Table 1) and focus on the most directly linked with urban or periurban areas.

These soil degradation processes in Europe generate total annual costs of 50 billion $€$. (EC, 2020a). Most of Table 1 issues are associated with the development of human activities, so authors take into account demographic and settlement trends.

The worldwide population in 2019 was 7.7 billion, and it is expected to grow to 10.8 billion in 2100 (United Nations, 2019). All regions will grow in total population, except Europe, which will suffer a decrease by 2100 . The aging of the world population is a fact, and in some regions, like Europe, it will be a more pressing phenomenon, where the share of elderly will arise near $30 \%$ by 2100 , and there will be more than a half million centenarians by 2050 (Eurostat, 2019).

Between 1975 and 2015, about $92 \%$ of worldwide urban centers population has grown and has doubled in $46 \%$ of cities. In 2015, 141 cities reached high population densities (above 20,000 people $/ \mathrm{km}^{2}$ ). In European cities, the density is approximately between 2,001 and 5,000 residents per $\mathrm{km}^{2}$, with predominantly mid-sized rather than large cities (EC, 2018). Focused on European older people (aged 65 years or more) in 2018 , the $42 \%$ were living in urban regions, a $38 \%$ in intermediate regions and only a $20 \%$ in rural regions (Eurostat, 2019).

Despite the fact that urban centers occupy less than 1\% (EC, 2018), and gray infrastructure (buildings, roads and other sealed surfaces) cover approximately 3\% (Edmondson et al., 2012) of the Earth's surface, they are one of the main sources of global

Table 1 Soil threats in Europe

\begin{tabular}{ll}
\hline Soil disturbance & Share of affected soil (EC, 2020a) \\
\hline $\begin{array}{l}\text { Contaminated } \\
\text { sites }\end{array}$ & 2.8 million potentially (but only 24\% are inventoried) \\
Soil sealed & $2.4 \%$ \\
Compaction & $23 \%$ \\
Losing carbon & cropland: $0.5 \%$ per year; petlands: $50 \%$ \\
Residual & $83 \%(21 \%$ of agricultural soils with cadmium concentrations above the limit for drinking water; and 6\% with \\
pesticides & heavy metal content potentially unsafe por food production) \\
Eutrophication & $65-75 \%$ of agricultural soils \\
Water erosion & $24 \%$ \\
Desertification & $25 \%$ at high or very high risk \\
\hline
\end{tabular}


environmental impacts, as well as being, possible the least prepared to face them (Filho et al., 2019).

The increase in urban population implies ensuring the supply of necessary resources (González-Méndez \& Chávez-García, 2020), their health and well-being, the development of productive activities, transport, among others. This translates into an intensification in the ecological footprint of cities (Zambon et al., 2019), due to generation of waste and emissions (Losco \& Biase, 2021), loss of greenness and biodiversity, and soil occupation (Filho et al., 2019). According to Gurney et al. (2015), cities are the main driver of climate change, emitting more than $70 \%$ of global fossil-fuel $\mathrm{CO}_{2}$, and account for between 60 and $80 \%$ of energy consumption (UN-Habitat, 2017).

The world consumption of biomass, fossil fuels, metals and minerals is estimated to double and the recycling sector is projected to triple in size from 2017 to 2060 (OECD, 2019), but only $12 \%$ of the materials used in Europe in 2017 come from recycling (Eurostat, 2020a). By 2050, waste generation across the world is expected to reach 3.40 billion tones, and only $19 \%$ of waste is recovery (The World Bank, 2018). In 2018, European cities generated $492 \mathrm{~kg}$ of municipal waste per capita, which $47 \%$ was recycled and composted (Eurostat, 2020b).

In order to carry out the state of the art of urban soils conditions and its association with human health, we applied a methodology focused on exploring ad hoc publications on official institutions websites, internet search engines as well as scientific reference databases. Based on this, we explore the use of Technosols in urban and periurban environments in the literature as a possible strategy to achieve the objectives of the European Green Deal and Sustainable Developments Goals proposed by United Nations.

\section{Results and discussion}

\section{Urban health}

The World Health Organization (WHO) defined a "healthy city as one that is continually creating and improving those physical and social environments and expanding those community resources which enable people to mutually support each other in performing all the functions of life and in developing to their maximum potential" (WHO, 1998). In 2008, WHO expressly indicated direct relationship between the health of cities and the health of their citizens (WHO, 2008).

Analyzing the health of cities is a complex purpose (Webster \& Sanderson, 2012), and WHO can be the reference framework in this area. WHO considers that the city environment has a double effect on the health of citizens and on their own perception of health (WHO 1994). Galea and Vlahov (2005) indicate physical environment of a city encompasses air, water, green areas, geological and climate conditions.

WHO (1994) developed its European Healthy Cities Network, with the aim of measuring the health of cities, and being the starting point for establishing improvement strategies. This requires the use of multisector indicators (health status, health services, lifestyle, infrastructures, environmental and socioeconomic indicators), due to the various connotations of health, and may vary depending on the source consulted (Table 2).

Few references include direct indicators of soil quality to evaluate urban health. For instance, Zambon et al. (2019) chose soil quality index to analyze urban footprint of land consumption. Recently, the European Commission proposes a list of soil health indicators for achieving the Sustainable Development Goals (SDGs) (EC, 2020a). The European Environmental Agency (EEA) currently uses several indicators to answer key policy questions, and there are a set about land and soil (EEA, 2019). One of the indicators included in this scope is the progress of management of contaminated sites and concludes that in 2011 the main sources of soil contamination in Europe were waste disposal and treatment $(38.1 \%)$, and industrial and commercial activities, that usually take place in urban or periurban settings. The most common soil pollutants in Europe are heavy metals $(34.8 \%)$ and mineral oils (23.8), both possible associated with industrial development.

On this basis, European cities are making efforts to analyze their level of sustainability and implementing improvement strategies, proof of this is the variety of urban rankings index available, such us European Soot-free City Ranking, European Green City Index, Europe Quality of Life Index, European Smart Cities Ranking, Smart Sustainable Cities Ranking. Akande et al. (2019) compare these urban assessment systems, highlighting the variability of the results, due to the level of definition of the ranking scope, the lack of a 
Table 2 Environmental quality indicators for healthy cities

\begin{tabular}{ll}
\hline Environmental quality indicators & References \\
\hline $\begin{array}{l}\text { Air quality, water quality, water and sewage services, noise pollution, radiation, open spaces, } \\
\text { infestations and food quality }\end{array}$ & WHO (1994) \\
$\begin{array}{l}\text { Derelict industrial sites, pedestrianization, sport and leisure facilities } \\
\text { Land contamination, local food growing, flood risk, }\end{array}$ & Webster and Sanderson (2012) \\
overheating, biodiversity & London Healthy Urban \\
Residential density, land use, urban sprawl and urban heat & Development Unit (2014) \\
$\begin{array}{l}\text { Physical, chemical, biological indicators. Presence of metals } \\
\text { Land use and urban design, food environment }\end{array}$ & Prasad et al. (2016) \\
$\begin{array}{l}\text { Soil quality index } \\
\text { Concentration PM2.5, emission of nitrogen oxides, municipal waste and recycling rate, ground } \\
\text { water of good chemical status, CO }{ }_{2} \text { emissions, Natura } 2000 \text { area in good quality, urban green } \\
\text { areas, soil sealing and surface water of good ecological status }\end{array}$ & Tresche et al. (2019) \\
$\begin{array}{l}\text { Soil health to fight rural poverty, for sustainable agriculture and forestry, for healthy and } \\
\text { sustainable diets and urban environments, for education. Soil health and landscapes for }\end{array}$ & EC (2020a) \\
$\begin{array}{l}\text { water, supporting bioenergy production, city greening and urban agriculture, circular } \\
\text { bioeconomy. Soil health for climate change mitigation and adaptation, supporting } \\
\text { biodiversity and soil health supported by an enabling environment }\end{array}$ & \\
\hline
\end{tabular}

type of reference city, the source of the data and it's weighting methodology. Analyzing the top3 sustainable cities that appears in the comparison made by Akande et al. (2019), we observe that two of the mentioned urban sustainability evaluation programs, chose Stockholm, Copenhagen and Zurich.

The interest of European cities to be an example in sustainability encourages cities to set ambitious goals, such as Copenhagen, plans to be the world's first carbon-neutral capital city by 2025 , and Stockholm, purposes to achieve $100 \%$ renewable energy by 2040 (Lafortune et al., 2019).

Analyzing more references to know the health status of European cities, the SDGs Index, shows the degree of compliance with the 17 SDGs on the Agenda 2030 of 45 capital cities and large metropolitan areas. The top 3 cities in that Index are Oslo, Stockholm and Helsinki. However, performance data suggest that Europe will not meet the SDGs by 2030. Possibly, because great challenges remain to be achieved in the objectives more related to the environmental field: SGD11 Sustainable cities and communities, SDG 12 Responsible Consumption and Production, SDG 13 Climate Action, SDG 14 Life Below Water and SDG 15 Life on Land (where urban green areas and soil sealing are evaluated). The results of the indicators and compliance with the SDG 3 Good Health and
Well-being show that nine cities have reached the objective, but the majority present challenges remain (Lafortune et al., 2019).

Currently, it is possible to know the degree of sustainable performance of the main cities of countries such as The United States of America, Italy and Spain (Lafortune et al., 2019). The analysis of the SGDs performance in 100 Spanish cities could help to face the challenges of urban clustering, since Spain is one of the European countries with the largest urban population share (Sánchez de Madariaga et al., 2018).

To assess the health of cities based on indicators that do not use a specific methodology or focus on a specific city, the environmental quality of the urban ecosystem could be a suitable option, due to their undeniable connection (Oliver \& Gregory, 2015). The EEA warns about environmental status in Europe (air pollution, climate change, exposure to chemicals and less ratio of green areas access), which represents a detriment to the health and quality of life of citizens, being the cause $13 \%$ of deaths in the European Union. What's more, EEA considers we could avoid these deaths if we focus on improving environmental quality. In fact, the COVID-19 pandemic illustrates it, probably been attributed to ecosystem degradation due to zoonosis processes, and one of the potential anthropic actions that accelerate it is urbanization 
(because of the land use change and the unsustainable consumption of natural resources) (EEA, 2020a).

Further, the climate change not only poses serious threats to the health of citizens, indeed is a severe source of stress to urban infrastructure and entire urban system (The World Bank, 2010), due to greater exposure and lower adaptation capacity (Filho et al., 2019). The vulnerability of cities, and therefore the well-being of their inhabitants, is most highly correlated with their degree of dependence on natural resources and ecosystem services, which in turn, the ecosystem services are linked to the level of impact and the ability to adapt to climate change (Barnett \& Adger, 2007). Maybe, the battlefields against the causes and consequences of climate change are our urban areas; therefore, it is key to propose a sustainable city model.

\section{Healthy soil}

Continuing with the relevance that ecosystem services represent on human welfare, authors consider convenient to list them (UN-Habitat and WHO 2020):

- Supporting (nutrient cycling, soil formation, primary production and vegetation medium).

- Provisioning (natural resources, water and food).

- Regulating (climate, pollution buffering, disease regulation and water purification).

- Cultural (esthetic, spiritual, educational and recreational).

Most of these services develop directly on the soil and influence by its conditions. Soil health is "the continued capacity of soils to support ecosystem services" (EC, 2020a). Defining this concept is not an easy task, and will need more discussion (Ling $\mathrm{Ng} \&$ Zhang, 2019) meanwhile authors want to add that soil health could be associated with soil ability to contribute to human health. Consideration that may be in accordance with its importance in safe warding human health (Montanarella \& Panagos, 2021).

Recently, the European Commission agree on 8 indicators to measure soil health (EC, 2020a): "presence of soil pollutants, excess nutrients and salts, soil organic carbon stock, soil structure including soil bulk density and absence of soil sealing and erosion, soil biodiversity, soil nutrients and acidity $(\mathrm{pH})$, vegetation cover, landscape heterogeneity and forest cover."
Human activities can compromise the health of soil because of the presence of polluting substances (Cachada et al., 2012) for example, emissions or discharges from industries, emissions from road traffic, agricultural fertilizers and pesticides, among others. As well, human development, can decrease soil physical, chemical or biological functionality, for example, due to the urbanization process ( $\mathrm{Li}$ et al., 2012), which causes compaction and sealing (Li et al., 2018), and reduces their capacity for food production, pollution attenuation, hydrological cycling and energy balance (Munafò et al., 2013).

Soil pollutants can affect human health through the following pathways of exposure: digestive route by consuming food that has accumulated pollutants from soils, dermal exposure, or by inhalation of vaporized pollutants. There is also the possibility of secondary contamination from soils, by coming into contact with contaminated water or by deposition of atmospheric pollutants (Rodríguez-Eugenio et al., 2018). Although it may seem otherwise, citizens are also in close contact with soil, not only due to their food intake, but also due to the development of their professional, sports and leisure activities, during their travels, even next to their homes. Urban soil surrounds us and is present in parks, along roads, sports fields, urban rivers, peripheral areas, near buildings and infrastructures (Li et al., 2018), as well as public or private gardens, playgrounds, beaches, brownfield sites, even in urban orchard gardens, rooftops and vertical gardens, which are increasing their presence in our cities.

The interactions between soil and health are complex, because the heterogeneity of urban soils and anthropic activities. Further, citizens expose to several types of pollutants, and the level of exposure and our autoimmune capacity can vary throughout our lives. So, cities can be areas of generation of pollution, as well as, which could be where most people are exposed (Table 3).

Table 3 analyzes urban quality pollution versus several land uses. In such way, topsoil and rubble subsoils in Berlin (Germany) show elevated concentrations of heavy metals and benzo[a]pirene (Abel et al., 2015), while artificial soils in Torun (Poland) are little altered by heavy metals (Charzyński et al., 2017). A recent research of lawn, forest, urban agriculture, green roof and peripheral agriculture soils in Santiago de Compostela (Spain) concludes that soils preserve 
Table 3 References related to urban soil pollution in Europe

\begin{tabular}{|c|c|c|}
\hline Study area & Urban soil quality assessment & References \\
\hline Italy land uses (included urban areas) & $\begin{array}{l}\text { Soil organic matter content and } \\
\text { bulk density in Italy }\end{array}$ & $\begin{array}{l}\text { Constantini and } \\
\text { Lorenzetti (2013) }\end{array}$ \\
\hline Topsoil, rubble soils, and natural soils in Berlin (Germany) & $\begin{array}{l}\text { Heavy metals and } \\
\text { benzo[a]pirene }\end{array}$ & Abel et al. (2015) \\
\hline $\begin{array}{l}\text { Sealed soil with asphalt or concrete, semipermeable and non-sealed soils in } \\
\text { Torun (Poland) }\end{array}$ & Heavy metals and soil sealing & $\begin{array}{l}\text { Charzyński et al. } \\
\text { (2017) }\end{array}$ \\
\hline Urban garden (allotment and home gardens) in Zurich (Switzerland) & $\begin{array}{l}\text { Physical, chemical, biological } \\
\text { and heavy metals content }\end{array}$ & $\begin{array}{l}\text { Tresch et al. } \\
\text { (2018b) }\end{array}$ \\
\hline Roadside linden trees soil, in Paris (France) & $\begin{array}{l}\text { Physical and chemical } \\
\text { parameters. Trace elements }\end{array}$ & $\begin{array}{l}\text { Quénéa et al. } \\
\text { (2019) }\end{array}$ \\
\hline $\begin{array}{l}\text { Lawn, forest, urban agriculture, green roof and periurban agriculture soils, } \\
\text { in Santiago de Compostela (Spain) }\end{array}$ & $\begin{array}{l}\text { Physical and chemical } \\
\text { parameters }\end{array}$ & $\begin{array}{l}\text { Paradelo et al. } \\
\text { (2020) }\end{array}$ \\
\hline Periurban area soil, designed for residential use, in Madrid (Spain) & As concentration & $\begin{array}{l}\text { Baragaño et al. } \\
\text { (2020) }\end{array}$ \\
\hline $\begin{array}{l}\text { Urban and periurban areas (included parks, open spaces, salt marshes, } \\
\text { agricultural lands and industrial areas), in Huelva (Spain) }\end{array}$ & $\begin{array}{l}\text { Potentially toxic elements } \\
\text { (PTEs) }\end{array}$ & $\begin{array}{l}\text { Guillén et al. } \\
\text { (2021) }\end{array}$ \\
\hline
\end{tabular}

from the negative consequences of urbanization processes, since they are in a similar state to natural soils. Despite this, collected values of $\mathrm{pH}$, salinity, $\mathrm{Ca}$ and $\mathrm{Mg}$ content, in urban gardens, surpass those of the periurban agricultural soils, mainly due to more intensive fertilization practices on urban gardens (Paradelo et al., 2020). The need to apply sustainable management is also manifested in the study of urban gardens in Zurich and considered crucial for the urban ecosystem (Tresch et al., 2018a). In turn, the high contamination data in the soils of Huelva (Spain) show how relevant is to know the health risk that soils may entail, with the intention of planning the land uses to preserve the health of people (Guillén et al., 2021).

$\mathrm{Li}$ et al. (2018) maintain that analyzing potential risk to health requires evaluating the level of exposure to the pollutant, and the severity of the damage it may cause (Li et al., 2018). Guillén et al. (2021) carry out research to assess the risk to adult or children health related to site-specific relative bioaccessibility of toxics elements present in urban soil. Although the results show that children are the segment of the population with the highest total carcinogenic risk, in many analyzed samples the carcinogenic risk levels exceeded limits proposed by the regulations, affecting both adults and children. A peripheral green and recreational area reached extremely risk, which in turn are the areas with the highest probability of residential development in its vicinity.

Directly related to the urbanization process, Charzyński et al. (2017) highlight soil sealing consequences for citizens well-being. Soil sealing is one of the greatest threats mentioned in the Soil Thematic Strategy (EC, 2006), as a syndrome of land degradation (Tobias, et al., 2018), and for developing its functions (Munafò et al., 2013). It consequently increases the risk of potential floods and water scarcity, endangers biodiversity, and leads to environmental change on a larger scale (EC, 2018). In addition, supposes the increase of urban heat island effects (EC, 2012).

Although efforts are being made to reverse soil degradation, some challenges remain to be faced. The sealed surface in Europe reaches 2,4\% (Table 1) and only $13 \%$ of urban land recycled (EEA, 2020a). In some cases, it is considered that soil sealing is not reversible (Constantini \& Lorenzetti, 2013). In addition, 2.323 contaminated sites remedied (EEA, 2020a), compared to 2.8 million potentially contaminated sites (Table 1).

Further, the presence of bacteria resistant to antibiotics has been detected in soils strongly affected by human presence (Popowska et al., 2011). Soil biodiversity is greatly affected in urban environments 
and the presence of human derived microorganisms can alter the soil ecosystem.

Healthy soil and health benefits

Therefore, as previously stated, due to degradation and presence of pollutants, some unhealthy soils can be a source of risk to human health (Baragaño et al., 2020). In fact, many authors defend this interconnection (Brevik et al., 2020; Wu et al., 2015). Likewise, a degraded soil can be a risk factor for our health; a healthy soil can be a component of well-being. Authors consider how a healthy soil silently watches over our health (Table 4).
One of the most significant benefits of urban soils related to hazard prevention and environment quality for citizens are "protection against rainstorm damage and flooding events by allowing water infiltration, decomposition of organic contaminants, retention and immobilization of contaminant, sequestration of carbon, buffering of climate mainly through cooling by evaporation, and a media for vegetation growth" (Lehmann, 2006).

Soil ability to absorb and transmit heat, and its contribution to urban heat island effect, has been studied related to land use by Bokaie et al. (2016). The areas with vegetation cover are those with the lowest average temperature; however, the areas with the

Table 4 Soil benefits for human health

\begin{tabular}{|c|c|}
\hline Soil benefits & References \\
\hline Protection against rainstorm damage and flooding. Media for vegetation growth & Lehmann (2006) \\
\hline \multirow[t]{2}{*}{ Allow biochemical cycles } & Lehmann (2006) \\
\hline & $\begin{array}{l}\text { Macías and Camps Arbestain } \\
\text { (2010) }\end{array}$ \\
\hline Erosion control & $\begin{array}{l}\text { Macías and Camps Arbestain } \\
\text { (2010) }\end{array}$ \\
\hline \multirow[t]{2}{*}{ Reduce urban heat island effect } & Lehmann (2006) \\
\hline & Bokaie et al. (2016) \\
\hline Host biodiversity & EC (2012) \\
\hline Cultural value and traditional landscape & $\begin{array}{l}\text { Constantini and Lorenzetti } \\
\text { (2013) }\end{array}$ \\
\hline Control pathogens. Provide antibiotics and medicines & Wall et al. (2015) \\
\hline $\begin{array}{l}\text { Urban agriculture for nutritional health and local economy. Personal wellness and community } \\
\text { betterment }\end{array}$ & Kumar and Hundal (2016) \\
\hline Touristic potential and landscape connectivity & Tobias et al. (2018) \\
\hline \multirow[t]{2}{*}{ Decontamination (retention phytoremediation and microbial bioremediation) } & Lehmann (2006) \\
\hline & Yap and Peng (2019) \\
\hline $\begin{array}{l}\text { Energy conservation in buildings, preventing acid rain, reduce sound exposure and enhance esthetic } \\
\text { value (rooftop with soil) }\end{array}$ & Cascone (2019) \\
\hline \multirow[t]{3}{*}{ Circular economy (use of wastes) } & Fourvel et al. (2019) \\
\hline & Barredo et al. (2020) \\
\hline & Ugolini et al. (2020) \\
\hline \multirow[t]{6}{*}{ Against climate change effects and to achieve emission neutrality (store organic carbon) } & Falkowski et al. (2000) \\
\hline & Lehmann (2006) \\
\hline & Edmondson et al. (2012) \\
\hline & Brevik et al. (2018) \\
\hline & $\begin{array}{l}\text { Navarro-Pedreño et al. } \\
\text { (2020) }\end{array}$ \\
\hline & $\begin{array}{l}\text { Montanarella and Panagos } \\
\text { (2021) }\end{array}$ \\
\hline
\end{tabular}


highest average temperature surprisingly were the bare land, and in second place the asphalt-paved surfaces, with a difference between the highest and lowest average of $8^{\circ} \mathrm{C}$. What is more, they concluded the risk of respiratory and heart diseases increases in residential areas most affected by urban heat island consequences.

Parallel to that, the incorporation of soils in rooftops as a substrate for vegetation also contributes to improve air quality levels, to conserve energy in buildings, as well, to reduce sound exposure (Cascone, 2019). Vegetated rooftops and green urban areas require healthy soil in order to ensure plant survival and improvement of esthetic value (Cascone, 2019).

The protection of the esthetic and cultural values of the soils and the characteristic landscapes that make up (Constantini \& Lorenzetti, 2013) enhance tourism and generate economic benefits for the local population (Tobias et al., 2018). In turn, the security of having quality food, which in the case of those grown in urban orchard gardens, promotes local community betterment and self-sufficiency (Kumar \& Hundal, 2016).

Soils (and of course, urban soils) play a main role in the greenhouse gases cycle and erosion control, so it will be essential to reach a soil optimal operating state, to be able to deploy all their purifying and regulating potential against the effects of climate change and to achieve emission neutrality (Montanarella \& Panagos, 2021). The loss of soil due to erosion processes leads to the loss of stored organic carbon in the surface horizon; in Mediterranean dry climate areas, the amount of organic carbon stored can decrease from 1-3 t C ha ${ }^{-1} \mathrm{~cm}^{-1}$ to $<1 \mathrm{t} \mathrm{C} \mathrm{ha}{ }^{-1} \mathrm{~cm}^{-1}$ (Macías \& Camps Arbestain, 2010). At the same time, waste management is a source of greenhouse gas emissions, when its destination is disposal or incineration; in addition, the essential components are not reincorporated into biochemical cycles (Macías \& Camps Arbestain, 2010). Greenhouse gases cycles $\left(\mathrm{CO}_{2}\right.$, $\mathrm{CH}_{4}$ and $\mathrm{N}_{2} \mathrm{O}$ ) can be regulated by soils (Brevik et al., 2018). Soils are a key piece in the global carbon cycle (Navarro-Pedreño et al., 2020); in fact, the vegetation and soil carbon reservoir on Earth is three times greater than the atmospheric pool (Falkowski et al., 2000). Therefore, some urban environments are a source of $\mathrm{CO}_{2}$ emission, and at the same time, urban ecosystems can be carbon reservoirs due to the storage in vegetation and in urban soils. Cambou et al. (2021) consider urban area soil organic carbon stock mainly depends on whether the soil is sealed or not. Carbon entry into sealed soils is practically impossible (Cambou et al., 2021), although Cambou et al. (2018) mention the importance of analyzing subsoil organic carbon storage, in urban sealed soils because total amount is relevant. In fact, approximately $69 \%$ of carbon storage in a citywide related to greenspace soil, $13 \%$ on sealed soil and $18 \%$ on vegetation (Edmondson et al., 2012). Hence, it is convenient to identify carbon storage controlling factors, in urban areas. For instance, in open urban soils, management practices (mulching or return of clipping) and land use (highest average soil organic carbon stock in garden public place and park and lowest in roadside) are crucial for soil organic carbon stock, among others (Cambou et al., 2021).

The compilation of numerous references on actions to mitigate and adapt to climate change in urban areas by Sharifi (2020) revealed that most of them are related to urban soils: land use, urban design (connections, ventilation, shading, orientation, water permeable surfaces and water harvesting), waste recycling and reuse, green roof, roof garden, green façade, network of parks, urban greenery and open spaces, urban nature protection (forests, green belt, protection of natural habitats), urban agriculture, xeriscaping and infill and brownfield development.

Soil can host at least one fourth of the Earth's biodiversity (EC, 2012). The biodiversity of microorganisms that soil host is crucial for the control of those that are pathogens for humans, for our stimulation immune system to control allergic diseases, for providing antibiotics and medicines (Wall et al., 2015), and as well as for the decontamination of soils through phytoremediation and microbial bioremediation (Yap \& Peng, 2019).

It seems interesting to mention that the EEA (2020a), in its healthy environment-healthy lives report, refers to the Sustainable Development Goals (SDG), approved by the United Nations (UN), which aims to reduce deaths related to environmental pollution, to reach a toxic free air, water and soil. Furthermore, it contributes an environmental factor list that cause impact on human health, as environmental human health indicators ("air quality, noise, indoor air quality, extreme weather, heatwaves, floods and chemicals"), but the soil is not included. Since soil host of most of the ecosystem services on which 
people's health depends, authors propose to analyze soil health as a possible human health stressor too.

\section{Europe green strategy}

Europe has proposed to be the first emission-neutral continent in 2050, based on the document the European Green Deal (EGD) (EC, 2019), protecting natural capital, and the health and well-being of citizens from environmental risks and impacts. To reach it, the European Commission has developed several strategies and regulations, in which the sustainable management of our natural resources (soil and waste as a resource) plays a main role:

- Biodiversity Strategy 2030 (for bringing nature back into our lives) designed for protecting at least $30 \%$ of the land and bringing back at least $10 \%$ of natural area under high-diversity landscape features (EC, 2020d).

Related to urban areas, the Biodiversity Strategy focuses on planting at least 3 billion additional trees (facilitating urban tree planting, as well) and requesting cities to develop ambitious Urban Greening Plans by the end of 2021. Efforts will direct towards protecting and increasing green urban ecosystem by using green infrastructure and nature-based solutions and reducing pollution to zero (soil, water and air). Further, addressing land take and restoring soil ecosystems (future Soil Thematic Strategy 2021), supporting the recovery of nature (at least 15\% of degraded ecosystems, prioritizing ecosystem with the most potential to capture and store carbon), limiting soil sealing and urban sprawl, and tackling pollution and invasive alien species

- European Climate Law with the aim of reducing $\mathrm{CO}_{2}$ emissions and increase sink of soils (EC, 2020e).

- Farm to Fork Strategy 2020 for designing a healthy and environmentally friendly food system, bringing back at least $10 \%$ of agricultural area under high-diversity landscape features (EC, 2020b).

- Circular economy action plan, for increasing recycling, promoting initiatives to reduce soil sealing, rehabilitate abandoned or contaminated brownfields and increase the safe, sustainable and circular use of excavated soils (EC, 2020c).

Waiting to know the objectives stipulated by the Soil Thematic Strategic 2021, the Seventh Environment Action Program (7th EAP) promote no net land take in the European Union by 2050 (EU 2013). Previously, the Thematic Strategy for Soil Protection launched on 2006 (EC, 2006) is considered as the precursor to soil protection initiative in Europe, for preventing and restoring soil degradation (Payá Pérez \& Rodríguez Eugenio, 2018).

The EGD is a great challenge for our current model of life, alien to nature, and it will undoubtedly require great efforts. The urban environment faces ambitious and necessary objectives for our health and quality of life. The involvement of cities and the European Commission in promoting and rewarding these endeavors is evident with the Urban Agenda for the EU-Pact of Amsterdam (signed in 2016) and the following awards. The European Green Capital Award launched in 2008 requires indicators of sustainable land use and green growth, among others. The European Green Leaf Award launched in 2014 aims at smaller cities and uses indicators of sustainable land use and circular economy, for instance (EC, 2021).

The EGD sets out to focus innovation and research efforts to achieve large-scale changes in adaptation to climate change, cities, soil, and oceans. The EGD considers that Europeans can reach their green commitment, by adopting Green Infrastructure (GI) methodology to support nature-based solutions (NBS). In accordance with the European Green Infrastructure Strategy (EC, 2013), GI is defined as "strategically planned network of natural and seminatural areas with other environmental features designed and managed to deliver a wide range of ecosystem services. GI is present in rural and urban settings." Despite the wide spectrum of environments for which GI is applied, in practice it seems to be mainly in urban areas (Chatzimentor et al., 2020). Possibly because its primary objective is to reproduce natural ecosystems services and that is essential for soils and human health (Coutts \& Hahn, 2015; EC, 2013) and because of less presence of green areas in urban areas. 
Are urban soils prepared for the green deal?

As previously stated, European soils face several threats (Table 1), among them, authors underline urban soil pollution (Table 3 ). This is not to say that all urban soils are degraded or polluted, as reflected in the findings of Paradelo et al. (2020). However, some urban soils need to be restored (Abel et al., 2015; Guillén et al., 2021), with the aim that cities can be service-facilitating ecosystems for the health and safety of their inhabitants.

In accordance with the EGD (EC, 2019), authors consider GI and NBS as the best tool for remediation of contaminated urban sites (Baragaño et al., 2020; Li et al., 2018), for carbon sequestration (GonzálezMéndez \& Chávez-García, 2020) and for reducing flooding risk and biodiversity conservation (Demiroglu et al., 2014). GI is capable of regulating temperature due to soil insulating properties, as well as because soils are the substrate on which vegetation develops, generating protection against temperatures with its shade and evapotranspiration. In Mediterranean environments, green walls can reduce around $59 \%$ of energy consumption for cooling (GonzálezMéndez \& Chávez-García, 2020). Berndtsson (2010) studied the crucial role that green roofs plays retaining pollutants carried during rain runoff.

Thus, we are interested in knowing how green European cities are at present and what resources will need for their greening plans.

The concept of green spaces can include "public green areas used predominantly for recreation such as gardens, zoos, parks, and suburban natural and forests, or green areas bordered by urban areas that are managed or used for recreational purposes" (WHO, 2016). Sometimes, research on urban green areas shows differences in the conclusions, perhaps due to the selection criteria of what is a green space or not. This is the case of the study carried out by Webster and Sanderson (2012) about healthy cities indicators, and the calculation of the surface area of urban green spaces varies widely, from $0.31 \%$ in Arezzo (Italy) to $61.53 \%$ in Gothenburg (Sweden).

Searching for references that have measured green areas, authors found the following approaches:

- SDG15 fulfillment of 45 European capital cities and large metropolitan areas (Lafortune et al., 2019): the indicators to measure the achievement of the SDG15, are: Natura 2000 Area in good quality (\%), urban green area (\%), soil sealing (\%) and surface water of good ecological status (\%). Only two cities (Oslo and Ljubljana) have achieved SDG15. Authors calculate an average value of the green area percentage present in the 45 cities chosen, obtaining $19.82 \%$. The urban green area percentage results vary greatly, authors provide the top3 (63.72\% Oslo, 55.18\% Marseille and $42.42 \%$ Ljubljana) and bottom3 (4.83\% Milan, $4.38 \%$ Amsterdam and $3.55 \%$ Porto).

- Proximity to green space (WHO, 2016): The generalized indicator in Europe is the accessibility to green areas, measured as the percentage of citizens living within $300 \mathrm{~m}$ from a public open area of minimum size 0.5 hectares from a distance of 15-min walk. Only 44\% European citizens have access to a green area $300 \mathrm{~m}$ away (Vandecasteele et al., 2019), maximum distance considered by WHO as adequate (EC, 2018).

- Criteria for the perception of citizen satisfaction (EC, 2020f): the percentage of total satisfaction with green area evaluated in selected cities and conclude that $77 \%$ of residents are satisfied with green spaces. Differences are observed in the percentage of satisfaction between cities in northern European countries, where citizens are more satisfied (96\% Malmö, 94\% Munich or Helsinki 94\%), while in southeastern European countries, satisfaction share is lower (29\% Athens, 30\% Naples or $31 \%$ Heraklion). It would not be appropriate to generalize that the geographical location of the countries can predefine satisfaction, since there are cities in southern Europe with high satisfaction rates $(86 \%$ Bologna, $81 \%$ Turin or 83\% Oviedo).

Authors compare data of green area percentage versus level of satisfaction (Table 5).

Analyzing Table 5 seems that key factor in the field of satisfaction is not so much the amount of green space percentage, but its accessibility and distribution (could be the case of Oslo and Munich). For example, a city with a large number of green spaces, but far from areas with the highest population density, provides less accessibility. In addition, cities with the same accessibility to green areas can obtain different satisfaction rates, so the quality and maintenance of green areas can also influence (EC, 2020f). 
Table 5 Percentage comparison of green area and citizen satisfaction

\begin{tabular}{lll}
\hline City & $\%$ urban green area (Lafortune et al., 2019) & $\%$ urban green area satisfaction (EC, 2020f) \\
\hline Oslo & $63.72 \%$ & $94 \%$ \\
Helsinki & $27.68 \%$ & $94 \%$ \\
Bratislava & $27.52 \%$ & $55 \%$ \\
Munich & $16.27 \%$ & $94 \%$ \\
London & $9.72 \%$ & $93 \%$ \\
Valleta & $7.00 \%$ & $44 \%$ \\
Athens & $6.90 \%$ & $29 \%$ \\
\hline
\end{tabular}

Consideration that is consistent with WHO (2016), in relation to planning of green areas, prioritizes the presence of small green areas close to areas with the highest population density, and large green areas in the surroundings, ensuring the adequate connection between the green areas. The relevant enquiry is that citizen could appreciate the views of green spaces from their own home, since it provides psychological benefits (WHO, 2016). As well as being able to spend time enjoying larger green spaces, to obtain more significant benefits for their health (a more active lifestyle, better environmental conditions, among others) (Lovell et al., 2014; Ridgley et al., 2020).

Furthermore, the size of green urban areas is a strong determinant in the soil organic carbon stock. Thus, larger green urban areas ( $\geq 5$ ha) have higher averages of soil organic carbon stock $(12.3 \pm 3.5 \mathrm{~kg}$ $\left.\mathrm{C} \mathrm{m}^{-2}\right)$, compared to averages $\left(9.6 \pm 4.0 \mathrm{~kg} \mathrm{C} \mathrm{m}^{-2}\right)$ of smaller areas ( $\leq 5 \mathrm{ha}$ ) (Cambou et al., 2021).

Therefore, cities can decide to increase the average of green areas to comply with the SDG15, to meet the considerations of the EGD, to improve the health of their citizens, to compensate for the loss of ecosystem services or just to increase ecosystem services. At this point, European cities will require options to develop their greening strategy, as sustainable as possible, without compromising resources as land use, water or soil.

The potentially green urban area is complicated to measure, a study of the stock of buildings in Vienna, estimated 12,000 ha of façades and 1,800 ha of roofs (Stangl et al., 2019). In fact, rooftops occupy 20-30\% of the total area of a city (González-Méndez \& Chávez-García, 2020), surface potentially suitable for revegetation.
Tobias et al. (2018) consider cities greening begins with brownfields regeneration, avoiding land take. Moreover, they conclude that recycled brownfields provide ecosystem services especially if they are unsealed, soil restored, and not compacted. Some European countries are betting on greenings existing surfaces, for example, rooftop. In 2014, there were $86,000,000 \mathrm{~m}^{2}$ of green roofs in Germany, with a clear annual growth trend (Cascone, 2019). In addition, to restore, expand and protect urban green areas (existing and potential), to achieve a fully functional urban ecosystem, they have to connect as an ecological network (Losco \& Biase, 2021).

Authors found articles that quantify the water needs of the new green city paradigm (Ruíz-Pérez et al., 2020). This article estimates the water footprint of an urban green area in Sevilla (Spain), using various patterns of plant species. Conclusions indicate that green areas with autochthonous scrub require the least volume of rainfall water (from 0,13 to $0,14 \mathrm{~m}^{3} \mathrm{~m}^{-2}$ ), the least volume of groundwater or irrigation (from 0 , 05 to $0,08 \mathrm{~m}^{3} \mathrm{~m}^{-2}$ ) and allow maximum recharge of aquifers and runoff (from 0,38 to $0,42 \mathrm{~m}^{3} / \mathrm{m}^{2}$ ). On the contrary, the choice of ornamental rosebush, requires the highest value for both rainwater input $(0,31$ $\left.\mathrm{m}^{3} \mathrm{~m}^{-2}\right)$ and irrigation input $\left(0,46 \mathrm{~m}^{3} \mathrm{~m}^{-2}\right)$ contributing the least amount of water to aquifers or runoff. To study the quantity and quality of water required to host the new urban-natural landscape, it is complicated, since it will depend on the type of climatic zone, the nutritional needs of the plant species and the systemic functions need to be recovered or enhanced.

The introduction of new green areas would lead to an increase in required water and soil resources for 
plant maintenance. With the laudable intention of bioremediation or revegetation, we can take in consideration not extracting soils from other areas, since we generate another problem. According to GonzálezMéndez and Chávez-García (2020), the most used substrate for GI is natural soil. The amount of topsoil from the surrounding areas imported to meet the land needs in urban areas estimated in 3 million of $\mathrm{m}^{3} \mathrm{yr}-1$ in France (Rokia et al., 2014). However, the search in the field of the soil footprint of city greening has not been so fruitful, being a possible new research area.

\section{Technosols for the European green deal}

Soils are a fundamental component of green infrastructure (Deeb et al., 2018), and a none common solution for the EGD urban needs (Deeb et al., 2020) could be use of wastes to construct new urban soils ( $\mathrm{Li}$ et al., 2018; Pruvost et al., 2020), as Technosols. In fact, urban soils can be made of exogenous materials and due to disturbances of human activities; they have lost their natural functions, becoming Technosols (IUSS 2015).

Based on the circular economy, we propose the use of waste from human activity for generating urban Technosols, avoiding new natural resource extractions and increasing valuation rates. Therefore, various references seek to verify whether these Technosols can be functional, testing capacity for plant growth, physicochemical parameters, reaching the conclusion that Technosols made by urban wastes can be a great option for urban greening (Barredo et al., 2020; Fourvel et al., 2019; Ugolini et al., 2020). Technosols even can be designed to store more organic carbon than natural soils (Rees et al., 2019), for thermal and water management and for biodiversity increased (González-Méndez \& Chávez-García, 2020), and for the reclamation of contaminated urban sites maintaining nutrient cycling functions (Hafeez et al., 2012). Technosols are an optimal solution that does not compromise environmental or human health (Baragaño et al., 2020; Herrán Fernández et al., 2016). A European regulatory framework that contemplates not only limitations but possible uses of waste and testing methodology to comply with would be very useful. Moreover, this will be act as an example for other regulations.
Therefore, designing and applying Technosols is a valid strategy to face climate change (Macías \& Camps Arbestain, 2010) and achieve a sustainable city model.

The modification of soil due to human activity would be contemporaneous with our presence on Earth. Named as anthropogenic soils and defined as "soils that have been modified, influenced, and/or altered by human activities" (Capra et al., 2015), they have been studied extensively, mainly since explosive urban development in the 2000s.

One of the first definitions that expressly indicated the concept of Technosols is "other soils dominated by technogenic soil materials (refers to all anthropogeomorphic soil materials created as the result of technical processes) a depth of $100 \mathrm{~cm}$ or a lithic or para-lithic contact, whichever is shallower" (Rossiter \& Burghardt, 2003). Lehman (2006) highlights the close relationship of Technosols with urban soils: "having technic soil material with an arte-fact content by volume of more than $50 \%$ for a depth of at least $10 \mathrm{~cm}$, starting within $10 \mathrm{~cm}$ from the soil surface." Considering technic soil as "soil material showing evidence of urban, industrial and related activities, and evidence is visible by a content of arte-facts by volume equal to or more than $20 \%$."

More recently, Technosols definition indicates that "contain artefacts $\geq 20 \%$ (by volume, weighted average) in the upper $100 \mathrm{~cm}$ of the soil surface or to continuous rock or technic hard material" (IUSS 2015).

Technosols have been created unintentionally (Santos et al., 2016) by humans, associated with the manipulation of the soils where human activities take place. As discussed before, humans can formulate soils with a specific purpose, with a greater or lesser technical complexity, based on empirical checks on its functional capacity. This second option is quite recent, and the majority of articles analyze the characteristics of Technosols applied in mining activities, possibly due to the need to deposit waste in landfill sites and to decontaminate mine lands (Arránz-González, 2011; Rivas-Pérez et al., 2016).

As mention before, notwithstanding, several authors' verified functional behavior of Technosols made by waste, this quality was not included in Technosols' own definition (Séré et al., 2008). This definition may be suitable for soils manipulated and altered by humans, for structural purposes (base for 
infrastructures, rubbles or waste landfills, or areas affected by a land movement), but for technically designed soils with a specific mission, a more detailed definition is needed. Most of the authors agree on its composition (artifacts, such as, wastes, materials, soils), and its human origin; however, the possible usefulness or the functional services Technosols provide are not mentioned. An initial approach to define Technosols in terms of their functional viability recently provided, in which the need to be suitable for the development of vegetation is attributed (Deeb et al., 2020).

Although we consider this definition as one of the most appropriate, it is necessary to point out that Technosols are soils designed with the intention of providing ecosystem services equal to those offered by natural soils, or to enhance an ecosystem service; therefore, it would surpass natural soils, ensuring human and environmental health.

In such a way, after discerning the environmental status of cities and analyzing the programs related to the Europe Green Strategy in the previous introduction, we carry out a bibliographic analysis on the use of made by waste Technosols, for improving urban soils conditions and inhabitant's health, as both should be objectives of any political action associated to the EGD.

\section{Technosols lexical form}

Using the Scopus online database for searching the word "Technosols," authors found 333 references (search scope abstract, article title and key words) and 1,081 references expanding to all search fields. In order to carry out a more accurate and focused study on articles based on the development and application of Technosols, authors define the quest scope limited to abstract, article title and key words, as our representative population.

If we explore the term "Technosol," 321 references appear, so authors consider that its use in the plural form is more widespread, choosing it as our official designation for this article. Due to the possible variations in the denomination, we analyze the possible use of similar words such as "Technosoil" or "Technosoils," from which almost no references are obtained, 8 and 7 references, respectively. The examination for the word "Tecnosol," yields scarce references, because it is translated into Spanish or Portuguese.

Mainly Russian, Polish and Bulgarian affiliation authors, appearing in just only $6 \%$ of the references, observe the use of the term "Technogenic soil" as a synonym for Technosol. It is not widespread use and it is confined to Eastern European countries, probably because Technosols are recognized in the Russian Soil Classification System as Technogenic superficial formations (IUSS 2015).

\section{Technosols interest evolution}

Observing the chronology of publications, the first reference that includes the word "Technosols" in its title dates from 2005. The second from 2006, possible because the term "Technosols," was first mentioned in 2003 (Rossiter \& Burghardt, 2003) and later was considered the introduction of the Technosols to the International Soil Classification System WRB in 2006 (IUSS 2006). Undoubtedly, the use of Technosols as a type of soil is very recent compared to the beginning of the study of soil by modern science. The search for the term "soil" in Scopus online database provides $1,049,826$ references, and the first reference dates from the year 1842 .

Analyzing the Technosols published references histogram (Fig. 1), authors observe an upward trend in the number of publications, reaching its maximum in 2018 with 59 references. Authors highlight the most prolific period with a total of 290 references (this implies $88 \%$ of the total), from 2013 to 2020. The average per year of the number of published references and citations is 21 and 186, respectively.

While we notice that the number of references is most likely to maintain growth dynamics, on the contrary, we cannot indicate the same in the area of the number of citations made per year (Fig. 1). Since 2013, the number of mentions has shown a strong increase, reaching its maximum in 2017 with 358 citations, however, from this moment on its trend reversed towards a drastic slowdown, not knowing the causes.

Investigating the most prolific writers in the field of Technosols, authors focus on the top5, with France (Schwartz, C.; Morel, J.L.; Watteau, F.; Séré, G) and Spain (Macías, F.) being the leading countries in research on this topic, covering $22.52 \%$ of total publications. It is worth mentioning the relevance of 
400
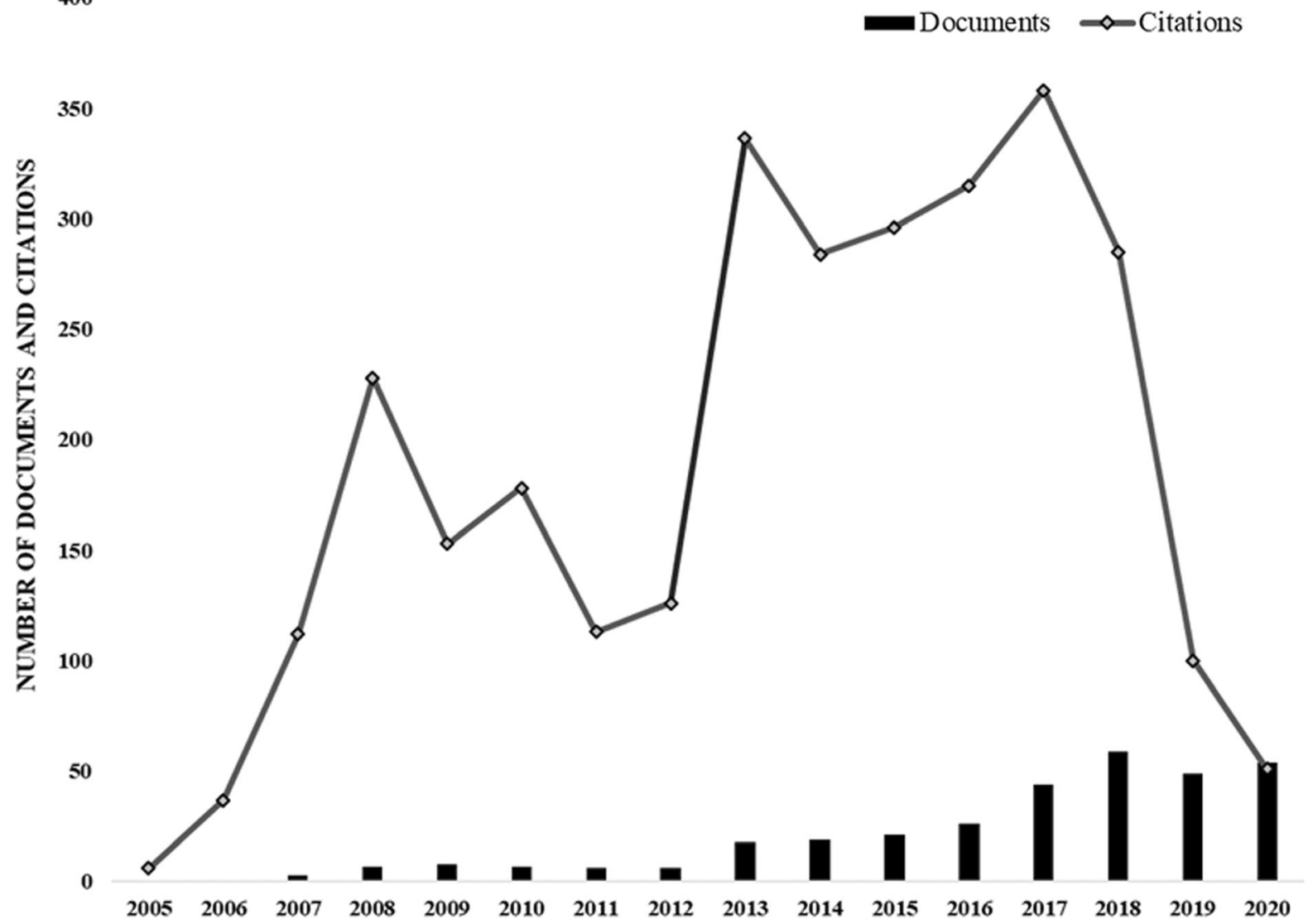

Fig. 1 Number of documents and citations per year

Eastern European countries, as they follow in the affiliation of the authors with the most publications (Pietrzykowski, M.; Charzynski, P.; Greinert, A.; Minkina, T.). The format of most references (87.99\%) corresponds to article, being the journal, the source type chosen in $92.19 \%$.

Technosols fields of use

Almost half of the references (151 articles) are included in the ambit of "Mining and industrial activity" (Fig. 2). Their main objective is to study anthropized soils due to the development of mining activities (Moreno-Barriga et al., 2017; Santos et al., 2019; Zornoza et al., 2017), in such way; many references analyze the evolution of soils over time, as well as studying the formulation of new Technosols to fill any deficiency or to amend the presence of polluting substances. In most cases, they are Technosols created with mining activity residues and will be applied in the mining operations themselves. In the industrial field, authors found some articles related to the petrochemical, textile and ammunition industry (Thouin et al., 2019).

The next largest group (Fig. 2), with 89 references, involves the use or study of Technosols in urban areas. Among issues addressed by authors (Baragaño et al., 2020; Charzyński et al., 2017; Rees et al., 2019) mainly evaluate quality of urban soils (soil sealing or compaction, contamination and carbon sequestration). As well, formulate new Technosols for soil improvement by using municipal waste, for instance, (Barredo et al., 2020; Deeb et al., 2020; Ugolini et al., 2020), which can be used for city revegetation (rooftops, parks, brownfield reclamation).

The 70 articles included in the "Investigation" category (Fig. 2) are documents that study pedogenesis, classification, formulation and analytical methods in general, without detailing the use of Technosols for a specific purpose. The references classified as 


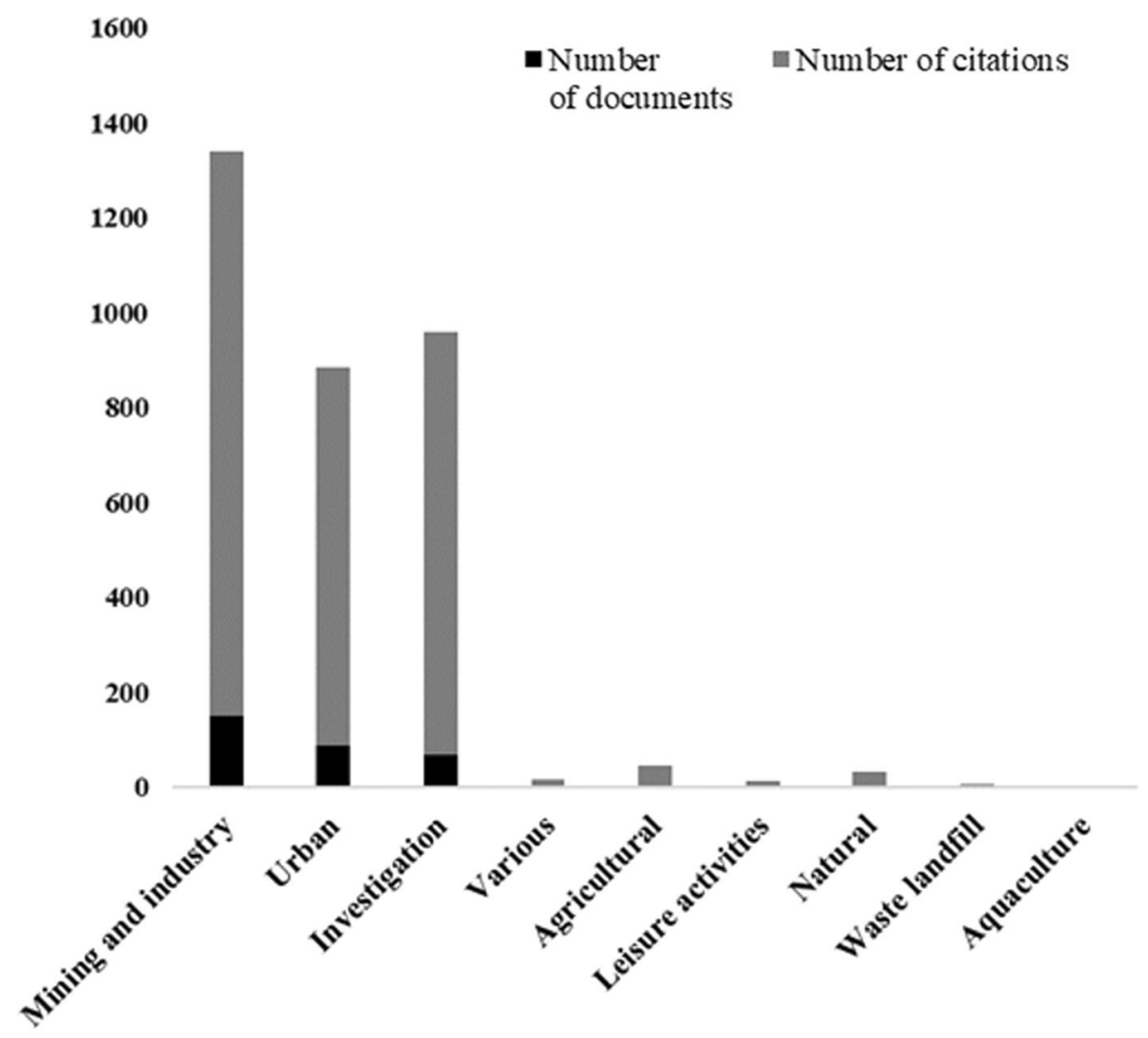

Fig. 2 Number of documents and citations related to scope of use (from 2005 to 2020)

"Various" (only five articles) are investigations that compare the soils located in different settings.

Authors mention the existence of a minority of articles related to activities as diverse as agriculture (Rokia et al., 2014), recreational activities as golf courses (Obear et al., 2017), natural spaces, waste landfill (associated with municipal waste dumps) and aqua culture (Cortinhas et al., 2020) (Fig. 2).

According to the data presented by Fig. 2, the references that arouse the most interest by the authors are mining and industry, followed by research references without a specific use, and thirdly those associated with urban areas.

Figure 3 illustrates the evolution in the number of published references based on the use of Technosols. Mining and urban areas publications trend follow a growth pattern (more pronounced in the case of mining). Although it is interesting to comment that the first publications cover the field of urban areas, a change occurs by the strong appearance of mining articles since 2010.
Health and technosols association

Another indicator to consider within our data analysis are the key words selected by the authors. As mentioned before, the word "Technosol" is used as key word (39 times), but to a lesser extent than word "Technosols" (107 times). Authors were surprised by the diversity of key words used, with 160 terms, representing almost half the number of published references, but none of them was the word "health." However, health-related terms are used, such as "heavy metals, soil pollutants, soil quality, carbon sequestration, phytoremediation, bioaccumulation or climate change."

Further, the term "health" it is expressly mentioned only once in the title of a reference: "Effects of different in situ remediation strategies for an aspolluted soil on human health risk, soil properties, and vegetation," (Baragaño et al., 2020). The scope of study is urban soils that are As-contaminated, and they experience adding organic wastes as an amendment and evaluate the human risk. 


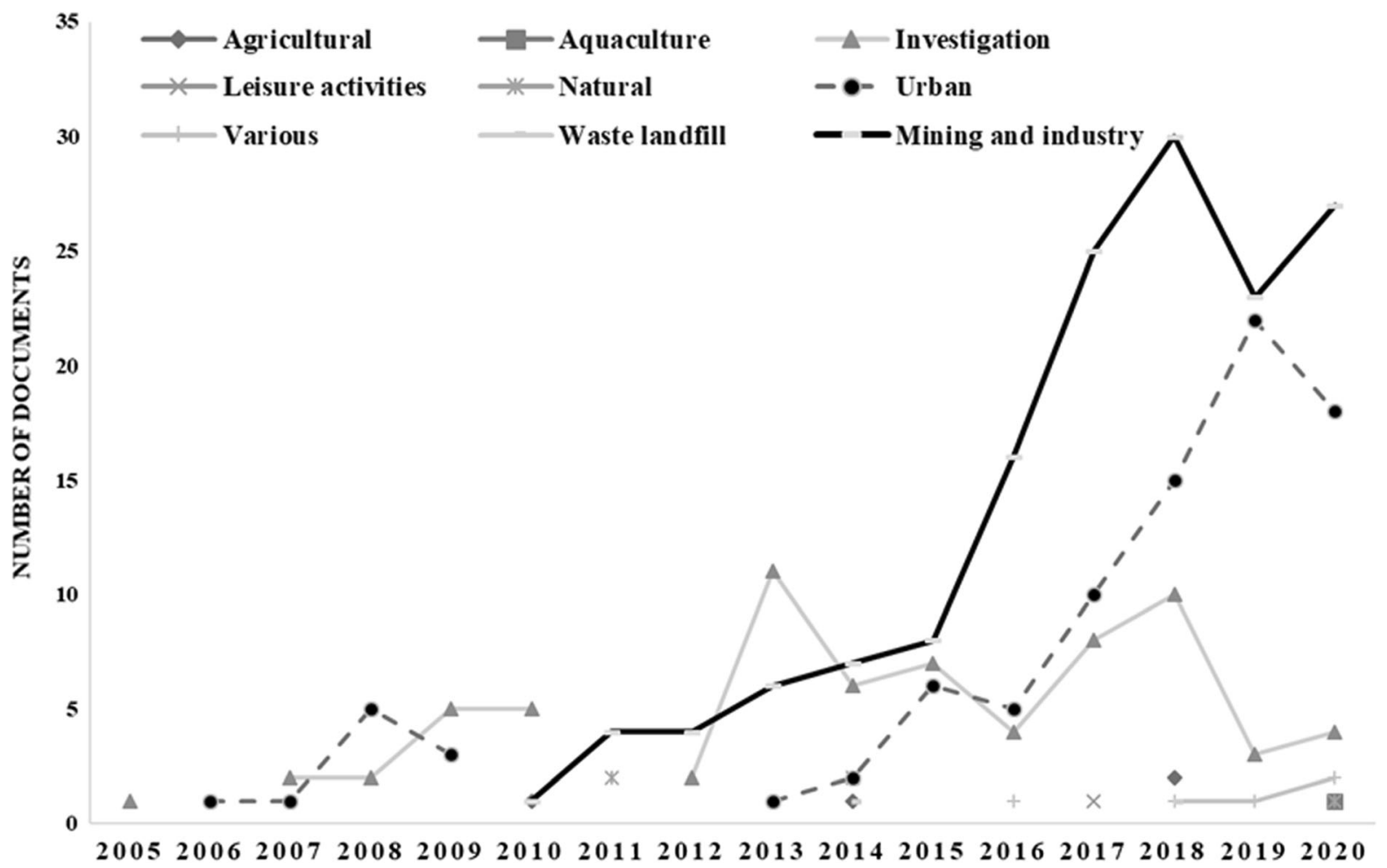

Fig. 3 Evolution in the number of documents related to scope per use and year

Several publications include considerations on people's health during the development of research, principally those that analyze the incidence of polluting substances (mainly heavy metals) in Technosols (Tsolova Tsolova et al., 2014). Despite being less common, there is also research focused on the health benefits of Technosols, as is the case of the interesting article developed by Ono et al. (2020). Their main intention is to study the capacity of the Technosols located in coastal zones to host trees that can reduce or avoid the devastating consequences of tsunamis on life and property.

Focusing on the articles on urban and periurban Technosols, we also find many references that, although they do not expressly mention health benefits, we consider that are closely related. The investigation of contaminated and degraded soils (soil sealing) with the intention of their regeneration covers most of the research articles in the field of urban Technosols. Some of them involve the use of constructed Technosols as amendments (Baragaño et al., 2020) and others analyze our cities underground
(Technosols) contamination degree (Charzyński et al., 2017; Moreno-Álvarez et al., 2020).

The second most prolific group involves the use of anthropogenic soils/Technosols as a substrate for GI development, by using municipal waste mostly for land reclamation (Barredo et al., 2020) and rooftops (Grard et al., 2020). Technosols benefit for climate change in the field of greenhouse gases management (Rees et al., 2019) also arouses interest in the scientific community and in the infiltration capacity for mitigation flood risk (Díaz-Sanz et al., 2020).

Fergusson (2017) establishes the relationship between the presence of pollutants in Technosols and the negative effect on human health and advises further research in this due to the wide variety of pollutants and their interactions.

Compilation of proposals

After reviewing the bibliography mentioned throughout this article, many authors agree that in the field of urban soils, many challenges remain to be faced. 
Consequently, this paper provides a compilation of their proposals:

- Strategies to enhance policy, sustainable soil management practices (Cambou et al., 2021; Montanarella \& Panagos, 2021; Tresch et al., 2018a, 2018b) and direct production processes towards sustainable models (EC, 2020a). In addition, seems to be a need for addressing the development of globalized regulations for soil protection, for using waste to formulate Technosols, and for standardizing assessment methods (Akande et al., 2019; Cambou et al., 2018).

- Authors agree on the requirement of expanding research on analyzing urban soil quality, to assess their level of ecosystem functioning as a service provider (Paradelo et al., 2020; Tresch et al., 2018a), and because additional studies can help to understand links between soils and health (Brevik et al., 2020; Fergusson, 2017). This purpose is not easy at all, due to the diversity of degradation processes and pollutants, their interactions, and peculiarities of each urban settlement (Cambou et al., 2021). Authors suggest starting by evaluating areas with the greatest direct exposure of the most sensitive population (playgrounds, hospitals, schools) (Li et al., 2018), as well as soils with possible presence of contaminants with higher level of health hazard (industrial or polluting activities) and estimating bioavailability (Guillén et al., 2021).

- Another reasonable approach to tackle this issue could be to enlarge upon key issues, as improving soil organic carbon storage (Cambou et al., 2021; Montanarella \& Panagos, 2021; Navarro-Pedreño et al., 2020; Rees et al., 2019), sealed soils restoration (Tobias et al., 2018) and to achieve GI and NBS on the premise of resource sustainability (Bouzouidja et al., 2020).

- It is also worth monitoring pollution or degradation sources and establishing programs for reduction or elimination. At the same time, relating contamination causes with the risks for the health of inhabitants is a way of establishing priorities for action. Land use planning might be in accordance with soil quality, to avoid exposing population to health hazards (Guillén et al., 2021) and to achieve urban sustainability (Losco \& Biase, 2021).
- Certainly make even greater progress on protecting green areas, after checking whether the land requires any compensation measure, and expanding urban greening based on key parameters and required resources (Cambou et al., 2021; González-Méndez \& Chávez-García, 2020; Rokia et al., 2014; Ruíz-Pérez et al., 2020). To this effect, it seems convenient to carry out an inventory of potential areas to host vegetation (Cascone, 2019; Stangl et al., 2019; Tobias et al., 2018) and to connect it (Losco \& Biase, 2021).

- For soils that need to be decontaminated or with functional deficiencies, it should be borne in mind that the application of amendments through the formulation of Technosols made by wastes (González-Méndez \& Chávez-García, 2020; Hafeez et al., 2012; Macías \& Camps Arbestain, 2010; Rees et al, 2019). In this way, planners could avoid using natural resources, reduce waste management impact and allow nutrients reincorporation to biochemical cycles of soil.

\section{Conclusions}

The present study addresses the state of the art of urban soils conditions, its links with urbanization and human health and contributes to the need of further research.

Although more than $60 \%$ of European soils are unhealthy, mainly because of the development of human activities, in reviewing the literature, no data found on how many of these soils correspond to urban areas. European trends reflect population growth and aging, as well; urban settlements expected to continue their expansion. This future perspective might increase ecological footprint of cities, and their contribution to climate change. Consequently, actions to mitigate its aftermaths are urgent in order to ensure urban soils capacity to provide ecosystem services and human well-being. Although European cities are making efforts to analyze and improve sustainability, existing data suggest that Europe will not meet SGDs by 2030 . Possibly, because great challenges remain to be achieved related to environmental goals.

Therefore, more information on the needs of urban soils to provide ecosystem services would help to establish a greater degree of accuracy on this matter. One significant finding to emerge from this study is 
that healthy soils might preserve human health, and urban healthy soils may provide equal or more benefits than natural soils. In fact, amount of carbon stored by green urban areas seem to be associated mainly to their size. For greening plans and avoiding land take, consulted authors propose brownfield regeneration and greening existing surfaces, since they are able to provide ecosystem services as well. The introduction of new green areas might lead to an increase in required water and soil resources for plant maintenance. Further research might explore quantity and quality of water required to host the new urban-natural landscape.

Additionally, with the laudable intention of bioremediation or revegetation, we can take in consideration not extracting soils from other areas, since we generate another problem. Having found scarce references on the amount of soil required for the new city paradigm, it is a field of study to address. Based on the premises of the circular economy, authors propose the use of waste from human activity for generating urban Technosols. The possibility of building Technosols with waste as a GI substrate could enhance the most required ecosystem functions for each area. It would be Technosols developed to increase the environmental performance of urban soils and human well-being.

After studying the references related to urban Technosols, authors found that even though it is recent, it arouses growing interest and they are applied in a wide variety of fields. Technosols definition maybe needs more discussion and authors provide one that includes its value as a provider of ecosystem services. It is relevant to underline ecosystem benefits of constructed Technosols are not expressly approached from the prism of human health.

Finally, authors provide a compilation of proposals and essentials highlighted by the authors of the aforementioned references, in relation to the improvement of urban soils as providers of ecosystem services as human health helpers.

\footnotetext{
Author's contribution TRE participated in the conceptualization, methodology, data curation, investigation, writing-draft preparation, review and editing; JNP participated in the conceptualization, methodology, investigation, writing-review and editing, supervision; IGL participated in methodology, writing-review and editing, supervision; MMV participated in the supervision, writingreview and editing; JBB participated in the supervision,
}

writing-review and editing, AAZ participated in the methodology, writing-review and editing.

Funding None.

\section{Declaration}

Conflict of interest There is no conflict of interest.

Consent for publication There is no conflict of interest. All the authors are informed and consent the publication of the article.

\section{References}

Abel, S., Nehls, T., Mekiffer, B., \& Wessolek, G. (2015). Heavy metals and benzo[a]pyrene in soils from construction and demolition rubble. Soils and Sediments, 15, 1771-1780. https://doi.org/10.1007/s11368-014-0959-4

Akande, A., Cabral, P., Gomes, P., \& Casteleyn, S. (2019). The Lisbon ranking for smart sustainable cities in Europe. Sustainable Cities and Society, 44, 475-487. https://doi. org/10.1016/j.scs.2018.10.009

Arránz-González, J. C. (2011). Mine soils associated with opencast coal mining in Spain: A review. Boletín Geológico y Minero, 122, 171-186

Baragaño, D., Gallego, J. L. R., Baleriola, G., \& Forján, R. (2020). Effects of different in situ remediation strategies for an As-polluted soil on human health risk, soil properties, and vegetation. Agronomy, 10, 759

Barnett, J., \& Adger, W. N. (2007). Climate change, human security and violent conflict. Political Geography, 26, 639-655

Barredo, O., Vilela, J., Gabisu, C., Besga, G., Alkorta, I., \& Epelde, L. (2020). Technosols made from urban an industrial wastes are a good option for the reclamation of abandoned city plots. Geoderma, 377, 114563

Berndtsson, J. C. (2010). Green roof performance towards management of runoff water quantity and quality: A review. Ecological Engineering, 36, 351-360

Bokaie, M., Kheirkhah Zarkesh, M., Daneshkar Arasteh, P., \& Hosseini, A. (2016). Assessment of Urban Heat Island based on the relationship between land surface temperature and land use/ land cover in Tehran. Sustainable Cities and Society, 23, 94-104

Bouzouidja, R., Béchet, B., Hanzlikova, J., Sněhota, M., Le Guern, C., Capiaux, H., Jean-Soro, L., Claverie, R., Joimel, S., Schwartz, C., Guénon, R., Szkordilisz, F., Körmöndi, B., Musy, M., Cannavo, P., \& Lebeau, T. (2020). Simplified performance assessment methodology for addressing soil quality of nature-based solutions. Journal of Soils and Sediments. https://doi.org/10.1007/s11368-020-02731-y

Brevik, E. C., \& Burgess, L. C. (2014). The influence of soils on human health. Nature Education Knowledge, 5(12), 1

Brevik, E. C., Pereg, L., Steffan, J. J., \& Burgess, L. C. (2018). Soil ecosystem services and human health. Environmental Science \& Health, 5, 87-92 
Brevik, E. C., Slaughter, L., Singh, B. R., Steffan, J. J., Collier, D., Barnhart, P., \& Pereira, P. (2020). Soil and human health: Current status and future needs. Air, Soil and Water Research, 13, 1-23

Cachada, A., Pato, P., Rocha-Santos, T., Ferreira da Silva, E., \& Duarte, A. C. (2012). Levels, sources and potential human health risks of organic pollutants in urban soils. Science of the Total Environment, 430, 184-192

Cambou, A., Saby, N. P. A., Hunault, G., Nold, F., Cannavo, P., Schwartz, C., \& Vidal-Beaudet, L. (2021). Impact of city historical management on soil organic carbon stocks in Paris (France). Journal of soils and sediments, 21, 1038-1052. https://doi.org/10.1007/s11368-020-02869-9

Cambou, A., Shaw, R. K., Huot, H., Vidal-Beaudet, L., Hunault, G., Cannavo, P., Nold, F., \& Schwartz, C. (2018). Estimation of soil organic carbon stocks of two cities, New York City and Paris. Science of the Total Environment, $644,452-464$

Capra, G. F., Ganga, A., \& Grilli, E. (2015). A review on anthropogenic soils from a worldwide perspective. Journal Soils Sediments, 15, 1602-1618

Cascone, S. (2019). Green Roof Design: State of the Art on Technology and Materials. Sustainability. https://doi.org/ 10.3390/su11113020

Charzyński, P., Plak, A., \& Hanaka, A. (2017). Influence of the soil sealing on the geoaccumulation index of heavy metals and various pollution factors. Environmental Science and Pollution Research, 24, 4801-5481

Chatzimentor, A., Apostolopoulou, E., \& Mazaris, A. D. (2020). A review of green infrastructure research in Europe: Challenges and opportunities. Landscape and Urban Planning, 198, 103775

Constantini, E. A. C., \& Lorenzetti, R. (2013). Soil degradation processes in the Italian agricultural and forest ecosystems. Italian Journal of Agronomy, 8, 28

Cortinhas, A., Caperta, A. D., Teixeira, G., Carvalho, L., \& Abreu, M. M. (2020). Harnessing sediments of coastal aquaculture ponds through technosols construction for halophyte cultivation using saline water irrigation. Journal of Environmental Management, 261, 109907

Coutts, C., \& Hahn, M. (2015). Green infrastructure, ecosystem services, and human health. International Journal of Environmental Research and Public Health, 12, 9768-9798

Deeb, M., Groffman, P. M., Blouin, M., Egendorf, S. P., Vergnes, A., Vasenev, V., Cao, D. L., Walsh, D., Morin, T., \& Séré, G. (2020). Using constructed soils for green infrastructure -challenges and limitations. The Soil, 6, 413-434

Deeb, M., Groffman, P., Joyner, J. L., Lozefski, G., Paltseva, A., Lin, B., Mania, K., Cao, D. L., McLaughlin, J., Muth, T., Prithiviraj, B., Kerwin, J., \& Cheng, Z. (2018). Soil and microbial properties of green infrastructure stormwater management system. Ecological Engineering, 125, 68-75

Demiroglu, D., Yucekaya, M., Coban, A., \& Gokce, D. (2014). Investigation of green infrastructure for sustainable cities: The Kilis case. Journal of Environmental Protection an Ecology, 15(3), 1199-1207

Díaz-Sanz, J., Robert, S., \& Keller, C. (2020). Parameters influencing run-off on vegetated urban soils: A case study in Marseilles. France. Geoderma, 376, 114455
EC. (2021). European green capital award 2021 and European green leaf award 2020. Rules of contest.

EC. (2006). Communication from the commission to the european parliament to the council, the european economic and social committee and the committee of the regions commission of the european communities. Thematic strategy for soil protection. Brussels, COM 231 final, 22/09/2006.

EC. (2012). Guidelines on best practice to limit, mitigate or compensate soil sealing. Luxembourg: Publications office of the European Union.

EC. (2013). Communication from the commission to the european parliament to the council, the european economic and social committee and the committee of the regions green infrastructure (gi) enhancing europe's natural capital. Brussels, COM/2013/0249 final, 06/05/2013.

EC. (2018). Joint Research Centre. Atlas of the Human Planet 2018 - A world of cities. Luxembourg: European commission, ISBN 978-92-79-98185-2, doi: https://doi.org/ 10.2760/124503, JRC114316.

EC. (2019). Communication from the commission to the european parliament to the council, the european economic and social committee and the committee of the regions commission of the european communities. The european green deal. Brussels, 11/12 /2019.

EC. (2020e). Proposal for a regulation of the european parliament of the council establishing the framework for achieving climate neutrality and amending regulation (EU) 2018/1999 (European Climate Law). Brussels, COM 80 final, 0036 (COD), 04/03/2020.

EC. . (2020). Report on the quality of life in European Cities, 2020. Publications Office of the European Union.

EC. (2020a). Caring for soil is caring for life. Ensure $75 \%$ of soils are healthy by 2030 for food, people, nature and climate. Report of the Mission Board for Soil health and food. Brussels. 2020.

EC. (2020b). Communication from the commission to the european parliament to the council, the european economic and social committee and the committee of the regions a farm to fork strategy for a fair, healthy and environmentally-friendly food system. Brussels, COM 381 final, 20/05/ 2020.

EC. (2020c). Communication from the commission to the european parliament to the council, the european economic and social committee and the committee of the regions a new circular economy action plan for a cleaner and more competitive Europe. Brussels, COM 98 final, 11/03/2020.

EC. (2020d). Communication from the commission to the european parliament to the council, the european economic and social committee and the committee of the regions commission of the european communities. eu biodiversity strategy for 2030. bringing nature back into our lives. Brussels, COM 380 final, 20/05/2020.

Edmondson, J. L., Davies, Z. G., McHugh, N., Gaston, K. J., \& Leake, J. R. (2012). Organic carbon hidden in urban ecosystem. Scientific Reports, 2, 963

EEA. (2019). Indicator assessment progress in management of contaminated sites. European Environment Agency. https://www.eea.europa.eu/data-and-maps/indicators/ progress-in-management-of-contaminated-sites-3/ assessment. Accessed 19 November 2020. 
EEA. (2020). Healthy environment, healthy lives: how the environment influences health and well-being in Europe. Publications Office of the European Union.

EEA. (2020b). Indicator assessment imperviousness and imperviousness change in Europe. European environment agency. https://www.eea.europa.eu/data-and-maps/ indicators/imperviousness-change-2/assessment. Accessed 24 November 2020.

EU. (2013). Decision No 1386/2013/EU of the european parliament and of the council of 20 november 2013 on a general union environment action programme to 2020 living well, within the limits of our planet. official journal of the European union L 354/171-200, 28/12/2013.

Eurostat. (2019). Ageing Europe. Looking at the lifes of older people in the UE. Luxembourg: Publication office of the European union.

Eurostat. (2020a). Circular material use rate. European Commission. https://ec.europa.eu/eurostat/databrowser/view/ cei_srm030/default/table?lang=en. Accessed 28 October 2020 .

Eurostat. (2020b). Municipal waste statistics. European Commission. https://ec.europa.eu/eurostat/statistics-explained/ index.php/Municipal_waste_statistics. Accessed 28 October 2020 .

Falkowski, P., Scholes, R. J., Boyle, E., Canadell, J., Canfield, D., Elser, J., Gruber, N., Hibbard, K., Högberg, P., Linder, S., Mackenzie, F. T., Moore, B., Pedersen, T., Rosenthal, Y., Seitzinger, S., Smetacek, V., \& Steffen, W. (2000). The global carbon cycle: A test of our knowledge of earth as a system. Science, 290, 291

Fergusson, L. (2017). Anthrosols and technosols: the anthropogenic signature of contaminated soils and sediments in Australia. Water, Air, and Soil pollution, 228, 269

Filho, E. L., Balogun, A., Olayide, O. E., Azeiteiro, U. M., Ayal, D. Y., Chávez Muñóz, P. D., Nagy, G. J., Bynoe, P., Oguge, O., Toamukumj, N. Y., Saroar, M., \& Li, C. (2019). Assessing the impacts of climate change in cities and their adaptive capacity: Towards transformative approaches to climate change adaptation and poverty reduction in urban areas in a set of developing countries. Science of the Total Environment, 692, 1175-1190

Fourvel, G. J., Vidal-Beaudet, L., Le Bocq, A., Thery, F., Brochier, V., \& Cannavo, P. (2019). Fertility of Technosols constructed with dam sediments for urban greening and land reclamation. Journal of soils and sediments, 19, 3178-3192

Galea, S., \& Vlahov, D. (2005). Urban health: Evidence, challenges, and directions. Annual Review of Public Health, 26, 341-365. https://doi.org/10.1146/annurev.publhealth.26. 021304.144708

Gómez-Baggethun, E., Gren, A., Barton, D.N., Langemeyer, J., McPhearson, T., O'Farrell, P., Andersson, E., Hamstead, Z., \& Kremer, P. (2013). Urban ecosystem services. In T. Elmqvist et al., Urbanization, Biodiversity and Ecosystem Services: Challenges 175 and Opportunities: A Global Assessment (pp. 175-251). Doi https://doi.org/10.1007/ 978-94-007-7088-1_11.

González-Méndez, B., \& Chávez-García, E. (2020). Re-thinking the Technosol design for greenery systems: Challenges for the provision of ecosystem services in semiarid and arid cities. Journal of Arid Environments, 179, 104191
Grard, B. J. P., Manouchehri, N., Aubry, C., Frascaria-Lacoste, N., \& Chenu, C. (2020). Potential of technosols created with urban by-products for rooftop edible production. International Journal of Environmental Research and Public Health, 17, 3191

Guillén, M. T., Delgado, J., Gómez-Arias, A., Nieto-Liñán, J. M., \& Castillo, J. (2021). Bioaccessibility and human exposure to metals in urban soils (Huelva, SW Spain): Evaluation by in vitro gastric extraction. Environmental Geochemistry and Health. https://doi.org/10.1007/s10653021-00814-4

Gurney, K. R., Romero-Lankao, P., Seto, K. C., Hutyra, L. R., Duren, R., Kennedy, C., Grimm, N. C., Ehleringer, J. R., Marcotullio, P., Hughes, S., Pincetl, S., Chester, M. V., Runfola, D. M., Feddema, J. J., \& Sperling, J. (2015). Climate change: truck urban emissions on a human scale. Nature, 525(7568), 179-181

Hafeez, F., Spor, A., Breuil, M., Schwartz, Ch., Martin-Laurent, F., \& Philippot, L. (2012). Distribution of bacteria and nitrogen-cycling microbial communities along constructed Technosol depht-profile. Journal of Hazardous Materials, 231, 88

Herrán Fernández, A., Lacalle, R. G., Vélez, I., del Burgo, M. J., Martínez Azkuenaga, M., \& Vilela Lozano, J. (2016). First results of Technosols constructed from municipal waste in Vitoria-Gasteiz (Spain). Spanish Journal of Soil Science, 6, 64-81

IUSS. Working Group WRB. (2006). World reference base for soil resources. World soil resources reports FAO.

IUSS. Working Group WRB. (2015). Base referencial mundial del recurso suelo 2014, Actualización 2015. Sistema internacional de clasificación de suelos para la nomenclatura de suelos y la creación de leyendas de mapas de suelos. Informes sobre recursos mundiales de suelos. Roma: FAO.

Kumar, K., \& Hundal, L. S. (2016). Soil in the City: Sustainably Improving Urban Soils. Journal of Environmental Quality, 45, 2-8. https://doi.org/10.2134/jeq2015.11.0589

Lafortune, G., Zoeteman, K., Fuller, G., Mulder, R., Dagevos, J., \& Schmidt-Traub, G. (2019). The 2019 SDG index and dashboards report for European Cities (prototype version). Sustainable development solutions network (SDSN) and the brabant center for sustainable development (Telos).

Lehmann, A. (2006). Technosols and other proposals on urban soils for the WRB (World Reference Base for Soil Resources). Int. Agrophysics, 20, 129-134

Li, G., Sun, G. X., Ren, Y., Luo, X. S., \& Zhu, Y. G. (2018). Urban soil and human health: a review. European Journal of Soil Science, 69, 196-215

Li, X., Wang, C., Zhang, G., Xiao, L., \& Dixon, J. (2012). Urbanization and human health in China: spatial features and a systemic perspective. Environmental Science and Pollution Research, 19, 1375-1384

Ling Ng, E., \& Zhang, J. (2019). The search for the meaning of soil health: Lessons from human health and ecosystem health. Sustainability, 11, 3697

London Healthy Urban Development Unit. (2014). Healthy Urban Planning Checklist. London. https://www. healthyurbandevelopment.nhs.uk/wp-content/uploads/ 2014/04/Healthy-Urban-Planning-Checklist-March-2014. pdf. Accessed 21 October 2020. 
Losco, S., \& Biase, C. (2021). Land Consumption Versus Urban Regeneration. Springer Nature Switzerland., 178, 228-239. https://doi.org/10.1007/978-3-030-48279-4_22

Lovell, R., Wheeler, B., Higgins, S., Irvine, K., \& Depledge, M. H. (2014). A Systematic review of the health and wellbeing benefits of biodiverse environments. Journal of Toxicology and Environmental Health, Part B, 17(1), 1-20

Luo, X., Yu, S., Zhu, Y., \& Li, X. (2017). Trace metal contamination in urban soils of China. Science of the Total Environment, 421-422, 17-30

Macías, F., \& Camps Arbestain, M. (2010). Soil carbon sequestration in a changing global environment. Mitigation and Adaptation Strategies for Global Change, 15, 511-529

Montanarella, L., \& Panagos, P. (2021). The relevance of sustainable soil management within the European Green Deal. Land Use Policy, 100, 104950

Moreno-Álvarez, J. M., Orellana-Gallego, R., \& FernándezMarcos, M. L. (2020). Potentially toxic elements in urban soils of Havana. Cuba. Environments, 7, 43

Moreno-Barriga, F., Díaz, V., Acosta, J. A., Muñoz, M. A., Faz, A., \& Zornoza, R. (2017). Creation of Technosols to decrease metal availability in pyritic tailings with addition of biochar and marble waste. Land Degrad. Develop, 28, 1943-2195

Munafò, M., Salvati, L., \& Zitti, M. (2013). Estimating soil sealing rate at national level-Italy as a case study. Ecological Indicators, 26, 137-140

Navarro-Pedreño, J., Almendro Candel, M. B., \& Zorpas, A. A. (2020). The increase of soil organic matter reduces global warming, myth or reality? Preprints.org. https://doi.org/10. 20944/preprints202012.0100.v1

Obear, G. R., Pedersen, M., \& Kreuser, W. C. (2017). Genesis of clay lamellae in golf course soils of Mississippi, USA. CATENA, 150, 62-70

OECD. (2019). Global material resources outlook to 2060: economic drivers and environmental consequences. OECD Publishing.

Oliver, M. A., \& Gregory, P. J. (2015). Soil, food security and human health: A review. European Journal of Soil Science, 66, 257-276. https://doi.org/10.1111/ejss.12216

Ono, K., Noguchi, H., Imaya, A., Ugawa, Y., Komoriya, A., Tachibana, R., Murakami, H., \& Kawahihashi, M. (2020). Soil hardness regulates the root penetration by trees planted on anthropogenic growing bases in coastal forests in Japan: New endeavors to reforest the coastal disaster prevention forests with high resilience for tsunami. Journal of Soils and Sediments. https://doi.org/10.1007/s11368-02002788-9

Paradelo, R., Herbón, C., \& Barral, T. (2020). Composition and chemical properties of the soils of the city of Santiago de Compostela, northwestern Spain. Journal of Environmental Quality. Special Section: urban soils research: SUITMA. https://doi.org/10.1002/jeq2.20094

Payá Pérez, A., \& Rodríguez Eugenio, N. (2018). Status of local soil contamination in Europe: Revision of the indicator. Progress in the management Contaminated Sites in Europe. ISBN 978-92-79-80072-6, doi:https://doi.org/10.2760/ 093804, JRC107508, Luxembourg: Publications Office of the European Union.

Pineo, H., Glonti, K., Rutter, H., Zimmermann, N., Wilkinson, P., \& Davies, M. (2018). Urban health indicator tools of the physical environment: A systematic review. Journal of Urban Health. https://doi.org/10.1007/s11524-018-0228-8

Popowska, M., Rzeczycka, M., Miernik, A., Krawczyk-Balska, A., Walsh, F., \& Duffy, B. (2011). Influence of soil use on prevalence of tetracycline. Antimicrobial Agents and Chemotherapy, 56(3), 1434-1443

Prasad, A., Gray, C. B., Ross, A., \& Kano, M. (2016). Metrics in urban health: Current developments and future prospects. Annual Review of Public Health, 37, 113-133

Pruvost, Ch., Mathieu, J., Nanun, N., Gigon, A., Pando, A., Lerch, T. Z., \& Blouin, M. (2020). The growth and macrofauna colonization in Technosols constructed from recycled urban wastes. Ecological Engineering, 153, 105886

Quénéa, K., Andrianjar, I., Rankovic, A., Gan, E., Aubry, E., Lata, J., Barot, S., \& Castrec-Rouelle, M. (2019). Influence of the residence time of street trees and their soils on trace element contamination in Paris (France). Environmental Science and Pollution Research, 26, 9785-9795. https:// doi.org/10.1007/s11356-019-04405-w

Rees, F., Dagois, R., Derrien, D., Fiorelli, J., Watteau, F., Morel, J. L., Schwartz, Ch., Simonnot, M., \& Séré, G. (2019). Storage of carbon in constructed technosols: In situ monitoring over a decade. Geoderma, 337, 641-648

Ridgley, H., Hands, A., Lovell, R., Petrokofsky, C., Stimpson, A., Feeley, A., Bedford, A., Fenech, B., Leeman, D., Skykes, E., Price, G., Sultan, H., Macintyre, H., Thorne, J., Hammon, J., Exley, K., Seymour, M., \& Brannan, M. (2020). Improving access to greenspace A new review for 2020. Public Health England.

Rivas-Pérez, I. M., Fernández-Sanjurjo, M. J., Núñez-Delgado, A., Monterroso, C., Macías, F., \& Álvarez-Rodríguez, E. (2016). Evolution of chemical characteristics of technosols in an afforested coal mine dump over a 20-year period. Land degradation and development, 6(27), 1640-1649

Rodríguez-Eugenio, N., McLaughlin, M., \& Pennock, D. (2018). Soil Pollution: A hidden reality. 142. Roma: FAO.

Rokia, S., Séré, G., Schwartz, C., Deeb, M., Fournier, F., Nehls, T., Damas, O., \& Vidal-Beaudet, L. (2014). Modelling agronomic properties of Technosols constructed with urban wastes. Waste Management, 34, 2155-2162

Rossiter, D.G., \& Burghardt, W. (2003). Classification of urban $\&$ industrial soils in the soil world reference base for resources: Working document second internat. conf. soils in Urban, industrial, traffic and mining. ISSS-AISS-SICS, Nancy.

Ruíz-Pérez, M. R., Alba-Rodríguez, M. D., \& Marrero, M. (2020). The water footprint of city naturalisation. Evaluation of the water balance of city gardens. Ecological Modelling, 424, 1090312

Sánchez de Madariaga, I., García López, J., \& Sisto, R. (2018), Los Objetivos de Desarrollo Sostenible en 100 ciudades españolas. Madrid: Red Española para el Desarrollo Sostenible (REDS).

Santos, E. S., Abreu, M. M., \& Macías, F. (2019). Rehabilitation of mining areas through integrated biotechnological approach: Technosols derived from organic/inorganic wastes and autochthonous plant development. Chemosphere, 224, 765-775

Santos, E.S., Arán, D., Abreu, M.M., \& de Verennes, A. (2016). Engineered soil using amendments for in situ rehabilitation 
of mine lands. In: Bio-geotechnologies for mine site rehabilitation, Elsevier, Amsterdam.

Séré, G., Schwartz, Ch., Ouvrard, S., Sauvage, C., Renat, J., \& Morel, J. L. (2008). Soil Construction: A Step for Ecological Reclamation of Derelict Lands. Journal Soils Sediments, 8(2), 130-136

Sharifi, A. (2020). Co-benefits and synergies between urban climate change mitigation and adaptation measures: A literature review. Science of the total environment, 75.

Stangl, R., Minixhofer, P., Hoerbinger, S., \& Kermer, L. (2019). The potencial of greenable area in the urban building stock. IOP Conference Series: Earth and Environmental Science, 323,012080

The World Bank. (2010). Cities and climate change: An urgent agenda. The International Bank for Reconstruction and Development.

The World Bank. (2018). What a Waste 2.0. A global snapshot of solid waste management to 2050. Washington: International bank for reconstruction and development.

Thouin, H., Battaglia-Brunet, F., Norini, M.-P., Joulian, C., Hellal, J., Le Forestier, L., Dupraz, S., \& Gautret, P. (2019). Microbial community response to environmental changes in a technosol historically contaminated by the burning of chemical ammunitions. Science of the Total Environment, 697, 134108

Tobias, S., Conen, F., Duss, A., Wenzel, L. M., Buser, C., \& Alewell, C. (2018). Soil sealing and unsealing: state of the art and examples. Land Degradation and Development, 29(6), 2015-2024

Tresch, S., Moretti, M., Le Bayon, R.-C., Mäder, P., Frey, D., Stehle, B., Kuhn, A., Munyangabe, A., \& Fliessbach, A. (2018). Urban soil quality assessment-a comprehensive case study dataset of urban garden soils. Frontiers in Environmental Science, 6, 136

Tresch, S., Moretti, M., Le Bayon, R.-C., Mäder, P., Zanetta, A., Frey, D., \& Fliessbach, A. (2018). A Soil gardener's influence on urban quality. Frontiers in Environmental Science, 6, 25. https://doi.org/10.3389/fenvs.2018.00025

Tsolova Tsolova, V., Blagoeva Hristova, M., Bech Borras, J., Roca Pascual, N., \& Dimitrov Banov, M. (2014). Pb, Cu and $\mathrm{Zn}$ geochemistry in reclaimed soils (Technosols) of Bulgaria. Journal of Geochemical Exploration, 144, 337-344

Ugolini, F., Baronti, S., Lanini, G. M., Maienza, A., Ungaro, F., \& Calzolari, C. (2020). Assessing the influence of topsoil and technosol characteristics on plant on plant growth for the green regeneration of urban built sites. Journal of Environmental Management, 273, 111168

UN-Habitat \& WHO. (2020). Integrating health in urban and territorial planning: a sourcebook. UN-Habitat and World Health Organization.

UN-Habitat. (2017). The world cities report 2016: Urbanization and development. new urban agenda, quito, ecuador: United Nations.

United Nations. (2019). World population prospects 2019. Department of economic and social affairs, population division, United Nations, New York: Volumen II: Demographic profiles, ST/ESA/SER.A/427.

Vandecasteele, I., Baranzelli, C., Siragusa, A., Aurambout, J.P., Alberti, V., Alonso Raposo, M., Attardo, C., Auteri, D., Barranco, R., Batista e Silva, F., Benczur, P., Bertoldi, P.,
Bono, F., Bussolari, I., Caldeira, S., Carlsson, J., Christidis, P., Christodoulou, A., Ciuffo, B., Corrado, S., Fioretti, C., Galassi, M. C., Galbusera, L., Gawlik, B., Giusti, F., Gomez, J., Grosso, M., Guimarães Pereira, Â., JacobsCrisioni, C., Kavalov, B., Kompil, M., Kucas, A., Kona, A., Lavalle, C., Leip, A., Lyons, L., Manca, A.R., Melchiorri, M., Monforti-Ferrario, F., Montalto, V., Mortara, B., Natale, F., Panella, F., Pasi, G., Perpiña, C., Pertoldi, M., Pisoni, E., Polvora, A., Rainoldi, A., Rembges, D., Rissola, G., Sala, S., Schade, S., Serra, N., Spirito, L., Tsakalidis, A., Schiavina, M., Tintori, G., Vaccari, L., Vandyck, T., Vanham, D., Van Heerden, S., Van Noordt, C., Vespe, M., Vetters, N., Vilahur Chiaraviglio, N., Vizcaino, P., Von Estorff, U., \& Zulian, G. (2019). The Future of Cities Opportunities, challenges and the way forward. Luxembourg: Publications Office of the European Union, ISBN 978-92-76-03847-4, doi:https://doi.org/10.2760/375209, JRC116711

Wall, D. H., Nielsen, U. N., \& Six, J. (2015). Soil biodiversity and human health. Nature, 528, 69-76

Webster, P., \& Sanderson, D. (2012). Healthy cities indicator a suitable instrument to measure health? Journal of Urban Health: Bulletin of the New York Academy of Medicine. https://doi.org/10.1007/s11524-011-9643-9

WHO. (1994). City Health Profiles: how to report on health in your city. ICP/HSIT/94/01 PB 02. Copenhagen: WHO Regional Office for Europe.

WHO. (1998). Health Promotion Glossary. WHO/HPR/HEP/ 98.1. Geneva: World Health Organization.

WHO. (2008). Closing the gap in a generation. Health equity through action on the social determinants of health. Final Report WHO/IER/CSDH/08.1. Geneva: Commission on Social Determinants of Health. World Health Organization.

WHO. (2016). Urban green spaces and health. WHO Regional Office for Europe.

Wu, S., Peng, S., Zhang, X., Wu, D., Luo, W., Zhang, T., Zhou, S., Yang, G., Wan, H., \& Wu, L. (2015). Levels and health risk assessments of heavy metals in urban soils in Dongguan, China. Journal of Geochemical Exploration, 148, 71-78

Yap, Ch.K., \& Peng, S.H.T. (2019). Cleaning contaminated soils by using microbial remediation: a review and challenges to the weaknesses. American journal of biomedical science and research, 2 (3).

Zambon, I., Serra, P., \& Salvati, L. (2019). The (Evolving) urban footprint under sequential building cycles and changing socio-demographic contexts. Environmental Impact Assessment Review, 75, 27-36

Zornoza, R., Gómez-Garrido, M., Martínez-Martínez, S., Gómez-López, M. D., \& Faz, A. (2017). Bioaugmentaton in Technosols created in abandoned pyritic tailings can contribute to enhance soil $\mathrm{C}$ sequestration and plant colonization. Science of the Total Environment, 593-594, 357-367

Publisher's Note Springer Nature remains neutral with regard to jurisdictional claims in published maps and institutional affiliations. 